Research Paper:

\title{
Different Dimensions of Iranian Nurses' Competency: A Scoping Review
}

\author{
Mahin Gheibizadeh $^{1}$ (D), Hadis Ashrafizadeh ${ }^{2 *}$ (D) \\ 1. Nursing Care Research Center in Chronic Diseases, Ahvaz Jundishapur University of Medical Sciences, Ahvaz, Iran. \\ 2. Student Research Committee, Ahvaz Jundishapur University of Medical Sciences, Ahvaz, Iran.
}

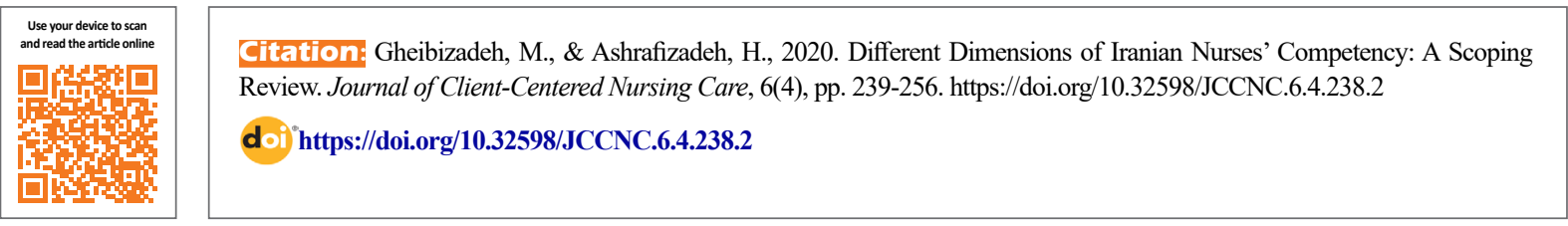

\section{(1) (8)}

Article info:

Received: 4 Apr 2020

Accepted: 22 Sep 2020

Published: 01 Nov 2020
Keywords:

Nurse, Professional competence, Iran, Review

\section{A B S T RA C T}

Background: Nurses are the largest group of healthcare providers. What is most important in acquiring nursing competency is knowing the competency levels and the factors, barriers, and strategies to increase nurses' competency. This study aimed to investigate the different dimensions of Iranian nurses' competency.

Methods: The present study is a scoping review. The related Persian articles were searched for in SID, Magiran, ISI, Scopus, PubMed, and other databases, from 1988 to 2019. The searched keywords included skill, competency, and nurse. After identifying the relevant studies, the data were selected, screened, and charted. Finally, the results were collated, summarized, and reported. Also, data extracted from the studies included the study design, sample size, research population, sampling method, key results, the concept of competency, and other information (such as the level of competency, data gathering tools, the language of study, etc.).

Results: Totally, 210 studies were fully reviewed and the data from 160 studies were extracted and analyzed. The results of this study were summarized in five themes: nurses' competency levels, nursing competency dimensions, effective factors in clinical competency, effective strategies for the promotion of clinical competency, and the relationship between nursing competency and other variables (such as job satisfaction, quality of work-life, emotional intelligence, and patient satisfaction).

Conclusion: The studies did not reach a collective consensus regarding the relationship between some variables and nursing competency. Besides, the use of different questionnaires made the comparison difficult. Therefore, further research is recommended in this area.

\section{* Corresponding Author:}

Hadis Ashrafizadeh, PhD. Candidate

Address: Student Research Committee, Ahvaz Jundishapur University of Medical Sciences, Ahvaz, Iran.

Tel: +98 (933) 5047127

E-mail: ashrafizadeh.h1993@gmail.com 


\section{Highlights}

- The present scoping review provided a comprehensive view of nursing competency in Iran. Also, most of the evidence was obtained from primary quantitative investigations.

- Among the studies, $26 \%$ evaluated competency through self-assessment and reported it to be at a desirable level.

- Based on the findings, a nurse is expected to have moral, clinical and special, cultural, emotional, and motivational competency.

- The relationships between clinical competency and other variables were explored in several studies.

- Effective strategies for the promotion of clinical competency are explained and summarized.

\section{Plain Language Summary}

Nowadays, the concept of nurses' competency is addressed as a key criterion in the provision of high-quality care and patient satisfaction and is considered as the main index for the evaluation of nurses' performance. This study aimed to investigate the different dimensions of Iranian nurses' competency. The dimensions of nursing competency were summarized in five themes: nurses' competency levels, nursing competency dimensions, effective factors in clinical competency, effective strategies for the promotion of clinical competency, and the relationship between nursing competency and other variables. Based on the findings, a nurse is expected to have moral, clinical and special, cultural, emotional, and motivational competency. Moreover, the present study explained and summarized the effective strategies for the promotion of clinical competency.

\section{Introduction}

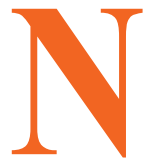

urses as the largest group of healthcare providers comprise $70 \%$ of the professional forces of the health care system (Azemian 2014). They play a crucial role in the continuation of care services (Memarian et al., 2007). Nowadays, the concept of nurses' competency is addressed as a key criterion in the provision of high-quality care and patient satisfaction and is considered as a main indicator for the evaluation of nurses' performance. It is also an ethical and legal necessity for care recipients, thereby, playing a pivotal role in the hospital survival rate (Cowin et al., 2008; Liu et al., 2009).

Tzeng has defined competency as a combination of capabilities, including analysis, interpretation, and the creation of interpersonal relationships (Tzeng 2004). Also, in medical sciences, competency is defined as an accurate judgment and getting used to the utilization of knowledge, technical skills, clinical reasoning, relations, emotions, values, and reflection in daily activities to provide services for people and society (Epstein \& Hundert 2002). Nursing literature emphasized the different dimensions of professional competency, including clinical, moral, managerial, and cultural competency. The profes- sional competency of nurses guides their professional practice and involves responsibility, accountability, continuity in proficiency and efficiency, critical thinking, the application of knowledge and skills, judgment, professional ethics, relationships, professional cooperation, professional management and leadership, care quality, self-control, and performance evaluation (Landa \& López-Zafra 2010; Tomar 2016). Each country's nursing system depends on nurses' competency, thus, this concept has received much attention in the recent century, so that many developed countries have authenticated the nurses' clinical competency through various approaches and techniques, such as continuing education, theoretical and practical exams, confirmed clinical work hours, and gaining academic degrees (DeNisco 2019).

Nursing managers in Iran have considered the promotion of service quality and the improvement of nurses' capabilities (Bahreini et al., 2011; Mazlum \& Nejad 2016). In Iran, rapid population growth, escalating economic problems, and increasing demand for community-based health services have necessitated the optimal use of facilities and resources, which has led to decentralization and privatization of the health care system by the government, in recent years. In this regard, the health sector faced many challenges, also, the criteria of the nursing 
workforce are designed to meet professional standards, which led to professional development, job satisfaction, and improving the quality of nursing care (Vanaki \& Memarian 2009). The studies conducted in Iran indicated the undesirable quality of services, also, care provision for patients was not based on scientific evidences (Kashf, Rakhshani \& Hashemi 2019; Ebrahimian et al., 2017; Aghamolayee et al., 2008; Tarahi et al., 2012). Another issue of concern is the increasing number of bachelor's degree students in nursing, which has caused worries regarding the graduates' preparedness for carrying out their responsibilities. This has been regarded as a debatable issue where insufficient knowledge exists (AtashzadehShoorideh et al., 2018; Ghodsbin \& Shafakhah 2008).

The identification of competency levels and the factors, barriers, and strategies for enhancing competency among nurses are of utmost importance in gaining nursing competency. Obtaining definite results in this field helps nurses and managers to be aware of various competency levels amongst nurses and identify weaknesses, strengths, barriers, and areas that require performance promotion to carry out further activities in those respects and consider them in the continuing education process.

To the best of our knowledge, no scoping reviews have been conducted in this field in Iran. Therefore, the present study aims to summarize the findings of recent studies in this area and determine the present knowledge status in terms of extent, range, and nature. The study also aims to identify research gaps in the previous studies to determine future research orientations and provide suggestions for further studies, such as systematic reviews and meta-analyses by referring to discrepancies.

\section{Materials and Methods}

\section{Study design}

This scoping review was conducted based on the Arksey and Omally modified methodology (Daudt, Van Mossel \& Scott 2013; Arksey \& O’Malley 2005). Scoping review is an exploratory research project resulting from a combination of knowledge that includes a relatively broad and concise set of sources or studies. It aims at the production of evidence, programs, and policies to determine future research orientations. Thus, scoping review is a prerequisite for systematic reviews and metaanalyses (Arksey \& O’Malley 2005). This type of research consists of six stages: 1 . Identifying the research question; 2. Identifying the related studies; 3. Selecting and screening the studies; 4. Charting the information and data; 5. Collating, summarizing, and reporting the results; and 6. consulting (optional).

This study was conducted based on the PRISMA-ScR (preferred reporting items for systematic reviews and meta-analyses extension for scoping reviews) checklist designed by Tricco et al. for systematic scoping review studies (Tricco et al., 2018). The a priori principle was also observed by registration in the researchers' pages.

\section{Research Questions}

Before searching the databases, the following research questions were considered.

1. What is the level of nurses' competency?

2. What are the dimensions of the different types of nursing competency?

3. What are the influencing factors in gaining the different types of competency?

4. What strategies have been proposed for the promotion of nurses' competency?

\section{Stages 1 and 2: Identifying the research questions and the relevant articles}

A primary search was conducted in some databases to identify the research questions. Afterward, the related articles were searched for in SID (Scientific Information Database), Magiran, Iran Medex, Web of Science, Scopus, PubMed, CINAHL, Google Scholar, Google, and DuckDuckGo databases, from September 15, 1988 to October 27, 2019, without language limitation. Since this study was a regional scoping review, Persian databases were searched separately. Also, a hand search was conducted in gray literature, including the reference lists of primary studies, Irandoc, and Civilica to find further related studies. The search components were assessed using three thesaurus systems, including MeSH term, Text Words, and Emtree. Besides, the searched keywords were classified into two categories: 1. Skill and competency; and 2. Nurse. The search strategy was developed by combining competency and skill with clinical, managerial, cultural, ethical, professional, nurse, and Iran. The search strategy for the PubMed database was as follows and modified for other databases. 
The search strategy used in PubMed from 1988 to 2019

((Competenc*[tiab] AND Clinical[tiab]) OR "Clinical Competency"[tiab] OR "Clinical Skill”[tiab] OR (Skill[tiab] AND Clinical[tiab]) OR “Competency Based Education"[tiab] OR (Education[tiab] AND Competency-Based[tiab]) OR (Education[tiab] AND “Competency Based"[tiab] OR (Competency[tiab]AND Cultural[tiab]) OR "Cultural Competence"[tiab] OR "management competency"[tiab] OR "Professional competency"[tiab] (Professional[tiab] AND competency[tiab]) OR "Legal competency"[tiab] OR (legal[tiab] AND competency[tiab] OR (management[tiab] AND competency[tiab]) OR “ethical competency"[tiab] OR (ethical[tiab] AND competency[tiab])) AND (Nurse[tiab] OR (Personnel[tiab] AND Nursing[tiab]) OR "Nursing Personnel"'[tiab] OR "Registered Nurses"[tiab] OR (Nurse[tiab] AND Registered[tiab])) AND (Iran[tiab] OR Iran[pi] OR Iran[ad]) AND 1988/09/15:2019/10/27[dp].

The inclusion criteria of the studies were the type of publication (article, thesis, and conference paper), language (Persian and English), study population (nurses, nursing managers, nursing professors, and nursing students), the type of study (primary and secondary), and being conducted on the various dimensions of competency in nursing profession, in Iran, at any time. If a study was in line with the objectives of the present research but its full-text was not available, three emails would send to the corresponding author at 10-day intervals. In case of no response, the study was omitted.

\section{Stage 3: Screening and selection of the studies}

All the studies obtained in the search stage were transferred to the EndNote (x7) software. In the screening stage, the researcher explored the titles and abstracts of the articles to eliminate the inconsistent studies. In the selection phase, two researchers completely investigated the full texts of the articles, using the PRISMA flowchart; they eliminated any discrepancy via collective agreement.

\section{Stage 4: Charting the data}

After the third stage, the researcher randomly selected some primary studies and developed a data extraction based on the related data. The data extracted from the studies included the name of the first author; publication year; the type of publication; study design; sample size; research population; sampling method; data collection instrument; research objective; key results; and the clini- cal competency level, sex, education level, mean age, workplace, and clinical work experience of the samples. The number of case and control groups, follow-up period, and the type of intervention were also extracted from interventional studies.

Stage 5: Collating, summarizing, and reporting the results

The obtained data were analyzed based on the framework of the data extraction form. The present study aimed to report the competency levels among nurses and students, influencing factors in gaining competency, designed instruments for the measurement of this concept, and other issues related to the concept. Finally, research gaps and the issues that required further investigation were introduced to be addressed in future studies and systematic reviews. Also, the results were presented in tables and graphs.

\section{Results}

\section{Characteristics of the studies}

After removal of the repeated articles ( $n=1145), 600$ studies were entered into the screening stage to evaluate their titles and abstracts. Totally, 210 studies were entered into the selection phase and 160 remained in the study (Figure 1). Table 1 represents the characteristics of the included studies. Accordingly, $81 \%$ of the studies were articles, including primary studies $(95 \%)$ and secondary studies (5\%). Besides, $72 \%$ of the studies were published in Persian. Additionally, $82 \%$ of the studies were conducted between 2011 and 2019. Moreover, the research population included nurses in $67 \%$ of the studies, and the mean sample size was 134. The lowest (Nesami et al., 2009) and highest (Ghanbari et al., 2017) sample sizes were five and 710 , respectively. Finally, $53 \%$ of the participants belonged to the age group of 25 to 35 years.

\section{Methodological aspects of the studies}

Table 2 summarizes the methodological characteristics of the included studies. Accordingly, 95\% of the studies were original papers. In terms of methodology, the articles were divided into three categories of observational, interventional, and qualitative studies. Additionally, $44 \%$ of the studies were descriptive and descriptiveanalytical, 24\% were quasi-experimental, and 26\% were qualitative studies. Data collection instruments included questionnaires, paper-and-pencil tools, in-depth and semi-structured interviews, and skill assessment checklists. In the interventional studies, a questionnaire, a skill 


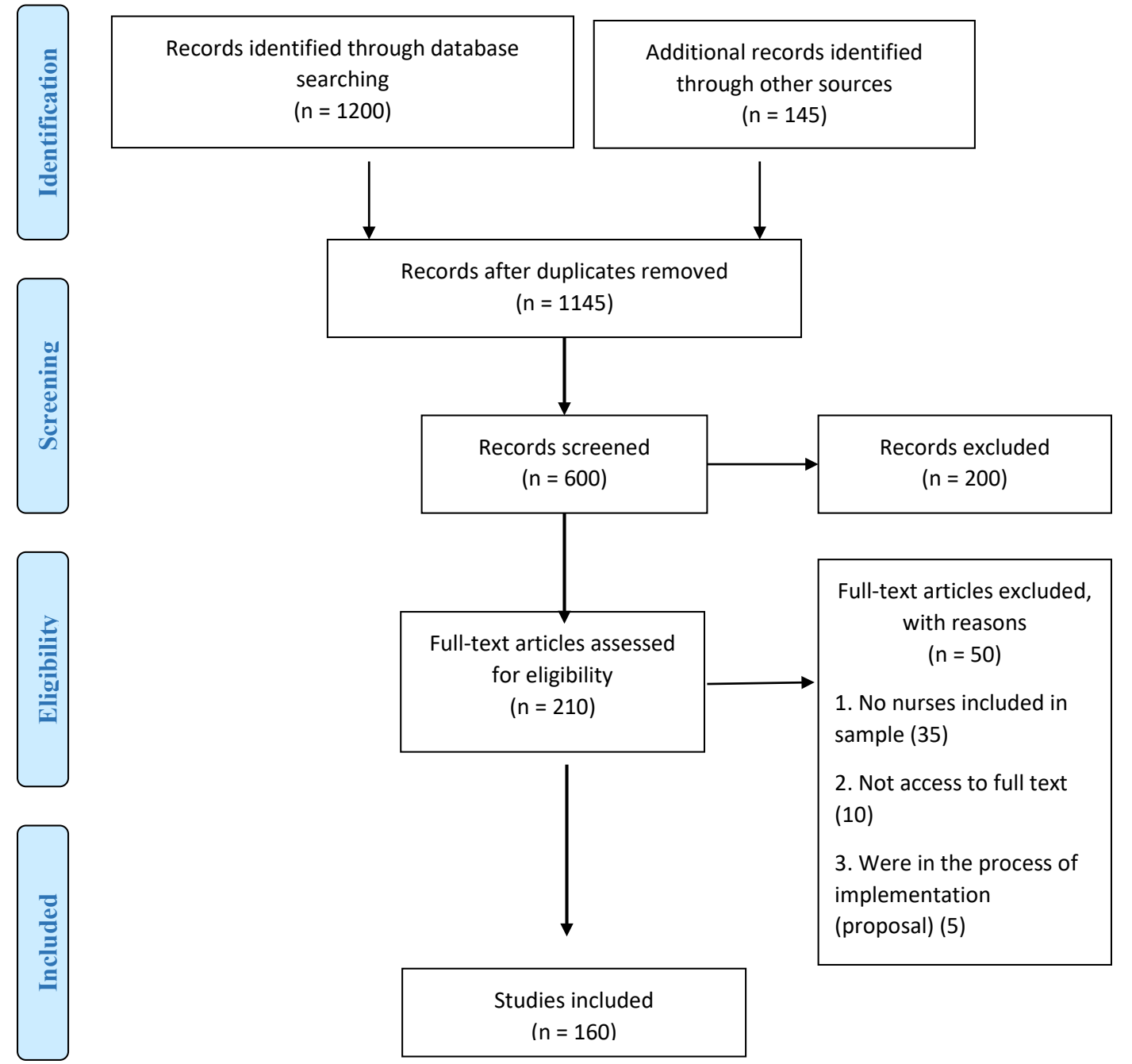

Figure 1. PRISMA flowchart for search strategy and results

Client- Centered Nursing Care

assessment checklist, or performance observation was used after the intervention to determine its effectiveness. The most widely used questionnaires in these studies were the Clinical Competence Assessment questionnaire developed by Benner and Mertoja and the Competence Inventory for Registered Nurses developed by Liu.

\section{Nursing competency}

Considering the included studies, the results were categorized into five themes (Figure 2). Tables 1, 2 and 3 summarize the information about nursing competency. Accordingly, the included studies explored various types of competency, including clinical or professional competency $(\mathrm{n}=140)$, ethical and communication competency $(n=11)$, cultural competency $(n=5)$, and managerial competency $(\mathrm{n}=4)$, amongst nurses. Also, $46 \%$ of the quantitative studies assessed the levels of the various types of competency among nurses and nursing students. Some other studies dealt with the effective variables in clinical competency. Moreover, strategies for the promotion of clinical competency were mentioned in $15 \%$ of the qualitative and quantitative studies and confirmed in further investigations. Table 2 shows the features of strategies for the promotion of clinical competency. Effective factors in clinical competency as well as competency dimensions were also identified in some other studies. Furthermore, some instruments have been developed for the assessment of nursing competency in Iran (Table 3). Finally, the results of this study were summarized in five themes: nurses' competency levels, nursing competency dimensions, effective factors in clinical competency, effective strategies for the promotion of clinical competency, and the relationship between nursing competency and other variables (job satisfaction, quality of work-life, 


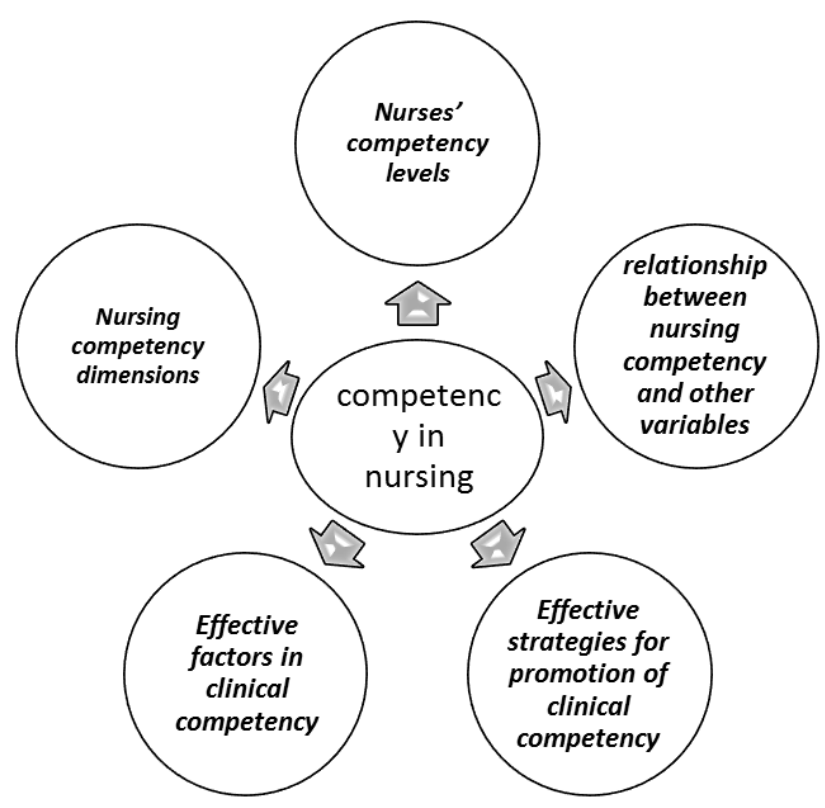

Figure 2. Structure of this scoping review for the categorization of the results of articles

Client- Centered Nursing Care

emotional intelligence, and patient satisfaction). These themes are fully explained in the discussion section.

\section{Discussion}

This study aimed to investigate the Iranian nurses' competency. To the best of our knowledge, this is the first scoping review on the different types and dimensions of nursing competency in Iran. The reviewed resources consisted of 160 articles, the characteristics of which are presented in different tables. These resources have reported a wide range of evidence that can be used in different settings. Considering the number of included studies, nursing competency is one of the challenges of interest for researchers.

First, the concept of competency has to be explored. Bagheri Nesami et al. conducted a concept analysis and stated that a competent nurse is the one who can manage patient care under various circumstances. These authors also categorized the main dimensions of a competent nurse into five major themes, including creativity, building appropriate relationships, having correct attitude (with two subthemes: values and attitudes and having a holistic view towards humans), knowledge, and skill (with three subthemes: repetition and practice, minimum error, and opportunity) (Nesami et al., 2009). The studied data were classified into five themes mentioned below.
Theme 1: Nurses' competency levels

Out of 160 included studies, 74 investigated the nurses' competency levels. Among these studies, 26\% evaluated competency through self-assessment and reported a desirable level of competency. Also, a large number of studies $(24 \%)$ pointed to the good level of clinical competency among nursing personnel and students (Jahanshahi et al., 2017; Heydari, Kareshki \& Armat 2016; Elhami et al., 2018; Soheilipour \& Farajzadeh 2016; Karimi-Moonaghi et al., 2015). However, 16\% of the studies reported a moderate level of competency in nurses (Mirlashari et al., 2016; Hassani et al., 2017; Soroush et al., 2016; Bahrami, Aliakbari \& Aein 2014; Ramezanzade Tabriz, Orooji \& Bikverdi 2017). Other studies that assessed nurses' clinical competency in different units, such as emergency wards; their competency levels in the provision of spiritual and other cares; and the competency levels of novice nurses indicated weak competency scores among the participants (Aliakbari \& Aein 2017; Adib-Hajbaghery, Zehtabchi \& Fini 2017; Jaafari Golestan, Vanki \& Memarian 2009). On the other hand, Mahmoudi et al. showed a good level of cultural competency among nurses (Mahmoodi et al., 2017). However, a moderate level of cultural competency was reported among nurses in two other studies (Bastami et al., 2016). Furthermore, Purfarzad et al. revealed a weak level of communication competency among nursing students (Purfarzad et al., 2019). Habashzadeh et al. also reported a weak level of professional competency among nursing managers (Habashzadeh et al., 2016). 
Table 1. Effective solutions for improving nursing competency

\begin{tabular}{|c|c|c|}
\hline Effective Solutions & Definition and Description of Effective Solutions & Expected Outcomes \\
\hline $\begin{array}{l}\text { Competency-based } \\
\text { participatory continuing } \\
\text { education }\end{array}$ & $\begin{array}{l}\text { Provision of nursing care based on professional perfor- } \\
\text { mance standards (responsibility, accountability, hav- } \\
\text { ing proper competency in the ward, the application of } \\
\text { knowledge and skills in clinical settings, building ap- } \\
\text { propriate relationships with the treatment team, the } \\
\text { application of care management, and self-regulation). } \\
\text { The program will provide the competency, skills, and } \\
\text { capabilities required by nurses for safe and effective } \\
\text { performance without the need for direct supervision. In } \\
\text { addition to clinical responsibilities, individuals will gain } \\
\text { technical, communicational, and critical thinking skills. }\end{array}$ & $\begin{array}{l}\text { - Promotion of scientific and skill competency } \\
\text { - Improvement of the quality of intensive nurs- } \\
\text { ing cares in open-heart surgery } \\
\text { - Improvement of the short and long-term out- } \\
\text { comes of cardiopulmonary resuscitation }\end{array}$ \\
\hline $\begin{array}{l}\text { Care-based professional } \\
\text { cooperation in teaching } \\
\text { apprenticeship courses }\end{array}$ & $\begin{array}{l}\text { Two individuals (instructor and mentor) guide students } \\
\text { in the clinical setting, aiming at creating a relationship } \\
\text { between the students' theoretical knowledge and prac- } \\
\text { tical skills. }\end{array}$ & $\begin{array}{l}\text { - Increase of students' cooperation in decision- } \\
\text { making } \\
\text { - Increase of critical thinking } \\
\text { - Increase of clinical competency }\end{array}$ \\
\hline $\begin{array}{l}\text { Transfer of knowledge } \\
\text { and experiences through } \\
\text { storytelling }\end{array}$ & $\begin{array}{l}\text { A story describes something occurring in a situation for } \\
\text { the presentation of key points and effective knowledge } \\
\text { transfer. This helps transfer theoretical sciences to clini- } \\
\text { cal settings. }\end{array}$ & Increase of managerial skills \\
\hline $\begin{array}{l}\text { Optimization of manage- } \\
\text { rial skills }\end{array}$ & $\begin{array}{l}\text { A program for the optimization of managerial skills enti- } \\
\text { tled network training obtained from Blake and Mouton's } \\
\text { managerial grid model (based on attention to produc- } \\
\text { tion and staff) together with the quality circles approach } \\
\text { for policymaking towards the cooperation of head nurs- } \\
\text { es in form of team-building approach }\end{array}$ & Increase of managerial skills \\
\hline $\begin{array}{l}\text { Multi-monitoring training } \\
\text { style }\end{array}$ & $\begin{array}{l}\text { A long-term mutual relationship based on friendship } \\
\text { and a positive attitude is created between the student } \\
\text { and the mentor. The student fulfills one's duties under } \\
\text { the mentor's leadership, and as time goes by, they will } \\
\text { be less dependent on the leader. }\end{array}$ & $\begin{array}{l}\text { - Improvement of nursing students' clinical } \\
\text { competency } \\
\text { - Increase of critical thinking } \\
\text { - Promotion of the quality of nursing care } \\
\text { - Reduction of the distance between theory and } \\
\text { practice }\end{array}$ \\
\hline $\begin{array}{l}\text { Reflective educational } \\
\text { strategies }\end{array}$ & $\begin{array}{l}\text { Reflection has been considered to be a manifestation of } \\
\text { professionalism, in which thought and practice are com- } \\
\text { bined, causing the individual to think about one's deeds. } \\
\text { Therefore, critical thinking results in the improvement of } \\
\text { professional activities. }\end{array}$ & $\begin{array}{l}\text { - Hidden curriculum management } \\
\text { - Promotion of nurses' clinical competency }\end{array}$ \\
\hline Educational portfolio & $\begin{array}{l}\text { Individuality-based learning and professional and learn- } \\
\text { ing needs occur in the portfolio. Portfolio refers to a set } \\
\text { of documents collected to show an individual's capabili- } \\
\text { ties and learning process over time. }\end{array}$ & $\begin{array}{l}\text { - Rethinking about performance } \\
\text { - Improvement of clinical competency }\end{array}$ \\
\hline $\begin{array}{l}\text { Achievement-based } \\
\text { education }\end{array}$ & $\begin{array}{l}\text { This educational method emphasizes unique work stan- } \\
\text { dards that the students are expected to present (know- } \\
\text { ing and being able to do). }\end{array}$ & $\begin{array}{l}\text { - Increase of cognitive and behavioral skills } \\
\text { - Promotion of clinical competency }\end{array}$ \\
\hline $\begin{array}{l}\text { Competency-based mas- } \\
\text { tery pattern }\end{array}$ & $\begin{array}{l}\text { The instructor knows the students' problems. The } \\
\text { students also know that they have sufficient time for } \\
\text { practice and receive appropriate feedback from the } \\
\text { instructor. }\end{array}$ & $\begin{array}{l}\text { - Improvement of general and special clinical } \\
\text { performance } \\
\text { - Promotion of knowledge and skills } \\
\text { - Reduction of failures and disappointments } \\
\text { among students }\end{array}$ \\
\hline $\begin{array}{l}\text { Nursing mentors commit- } \\
\text { tee or the positioning } \\
\text { of experienced nurses as } \\
\text { mentors }\end{array}$ & $\begin{array}{l}\text { Making use of qualified nurses as mentors in the clinical } \\
\text { setting }\end{array}$ & $\begin{array}{l}\text { - Increase of novice nurses' competency in psy- } \\
\text { chomotor, cognitive, and emotional domains }\end{array}$ \\
\hline
\end{tabular}




\begin{tabular}{|c|c|c|}
\hline Effective Solutions & Definition and Description of Effective Solutions & Expected Outcomes \\
\hline $\begin{array}{l}\text { Situational leadership } \\
\text { model }\end{array}$ & $\begin{array}{l}\text { Hersey-Blanchard situational leadership model rep- } \\
\text { resents four leadership styles consisting of two main } \\
\text { components, namely task-orientation and behavior- } \\
\text { orientation. }\end{array}$ & $\begin{array}{l}\text { - Promotion of nurses' communication compe- } \\
\text { tency }\end{array}$ \\
\hline $\begin{array}{l}\text { Effectiveness of online } \\
\text { simulator }\end{array}$ & $\begin{array}{l}\text { Online simulator is a part of the educational services for } \\
\text { working with ventilator. Simulator refers to the software } \\
\text { that provides all or some parts of a clinical experience in a } \\
\text { safe environment without the fear of hurting the patients, } \\
\text { thereby, providing the ground for efficient learning. }\end{array}$ & $\begin{array}{l}\text { - Increase of the effectiveness of memorization } \\
\text { - Increase of the quality of clinical training } \\
\text { - Increase of the students' clinical competency } \\
\text { in working with ventilator }\end{array}$ \\
\hline $\begin{array}{l}\text { Risk management in } \\
\text { hospitals }\end{array}$ & $\begin{array}{l}\text { Provision of response policy, accountability, and stan- } \\
\text { dard practice guidelines for emergency activities in dif- } \\
\text { ferent hospital wards in case of accidents, disasters, and } \\
\text { internal or external incidents can affect hospital staff, pa- } \\
\text { tients, visitors, and the society. }\end{array}$ & $\begin{array}{l}\text { Increase of nurses' communication compe- } \\
\text { tency, increase of capacity, continuation of vital } \\
\text { services, support and logistics, restoration of } \\
\text { the command and control dimension, and hos- } \\
\text { pital preparedness }\end{array}$ \\
\hline $\begin{array}{l}\text { Supportive clinical } \\
\text { environment during ap- } \\
\text { prenticeship }\end{array}$ & $\begin{array}{l}\text { Supportive clinical environment focusing on facilitation } \\
\text { of learning }\end{array}$ & $\begin{array}{l}\text { Increase of clinical competency score in the fol- } \\
\text { lowing dimensions: helping patients, training, } \\
\text { and therapeutic measures }\end{array}$ \\
\hline $\begin{array}{l}\text { Training how to cope with } \\
\text { accidents and disasters }\end{array}$ & $\begin{array}{l}\text { Development of an educational plan for dealing with ac- } \\
\text { cidents and disasters and training the personnel to ex- } \\
\text { ecute it in emergency cases }\end{array}$ & $\begin{array}{l}\text { Promotion of nurses' clinical competency in re- } \\
\text { sponse to accidents and disasters }\end{array}$ \\
\hline Stress inoculation training & $\begin{array}{l}\text { Stress inoculation training is a cognitive-behavioral tech- } \\
\text { nique in which individuals pass through their personal } \\
\text { experiences and receive a combination of cognitive and } \\
\text { behavioral techniques for coping with stress. Stress cop- } \\
\text { ing skills are learned when individuals are positioned in } \\
\text { stressful situations. }\end{array}$ & $\begin{array}{l}\text { - Reduction of stress } \\
\text { - Increase of job satisfaction } \\
\text {-Improvement of the quality of working life } \\
\text { - Promotion of clinical competency }\end{array}$ \\
\hline Multimedia training & $\begin{array}{l}\text { In multimedia training, individuals are provided with } \\
\text { materials and are required to seek for learning and solv- } \\
\text { ing their problems. This method includes activities in } \\
\text { which individuals can actively get involved in learning } \\
\text { both individually and in groups. }\end{array}$ & $\begin{array}{l}\text { Increase of clinical competency in cognitive and } \\
\text { attitude domains }\end{array}$ \\
\hline $\begin{array}{l}\text { Tailored graduate pro- } \\
\text { gram based on needs, } \\
\text { compatibility, and perfor- } \\
\text { mance }\end{array}$ & $\begin{array}{l}\text { Tailored graduate programs are more concise, compared } \\
\text { with normal ones, because of the nature of mentorship } \\
\text { continuing education and support and logistics. They are } \\
\text { also accompanied by more job responsibilities and help } \\
\text { develop future leadership roles. }\end{array}$ & $\begin{array}{l}\text { - Increase of self-efficacy } \\
\text { - Reduction of anxiety } \\
\text { - Reduction of the distance between theory and } \\
\text { practice } \\
\text { - Promotion of clinical competency }\end{array}$ \\
\hline
\end{tabular}

Client- Centered Nursing Care

Among the included studies, 68 evaluated the nurses' clinical competency via self-assessment, while six others used an objective structured clinical examination or performance observation. Among these six studies, three, two, and one reported weak, good, and moderate competency among nurses, respectively. It is worth mentioning that the studies evaluating clinical competency via self-assessment are weaker, compared with those using different techniques, such as peer-assessment and performance observation.

In a mixed-method study, Alavi and Irajpour (2004) assessed the viewpoints of clinical nursing teachers to determine the optimum characteristics of clinical competencies' evaluation. Their results indicated five major themes of evaluation indices, including criteria for eval- uation context, criteria for evaluation content, criteria for evaluation process, criteria for grading students, and criteria for evaluation outputs. According to the nursing teachers who participated in their study, the most important indices were 'paying attention to the overall and specific objectives of assessment for instructors and students' and 'paying attention to the priorities of clinical education,' while the least important one was 'paying attention to hidden or informal curriculum' (Alavi \& Irajpour 2014). A research gap that came to notice was the heterogeneity among the results. Various questionnaires and instruments were used for the assessment of clinical competency in different wards; this issue hindered the comparison of the results. Additionally, since various investigations used different questionnaires for the 
Table 2. Characteristics of articles on competency in Iranian nurses

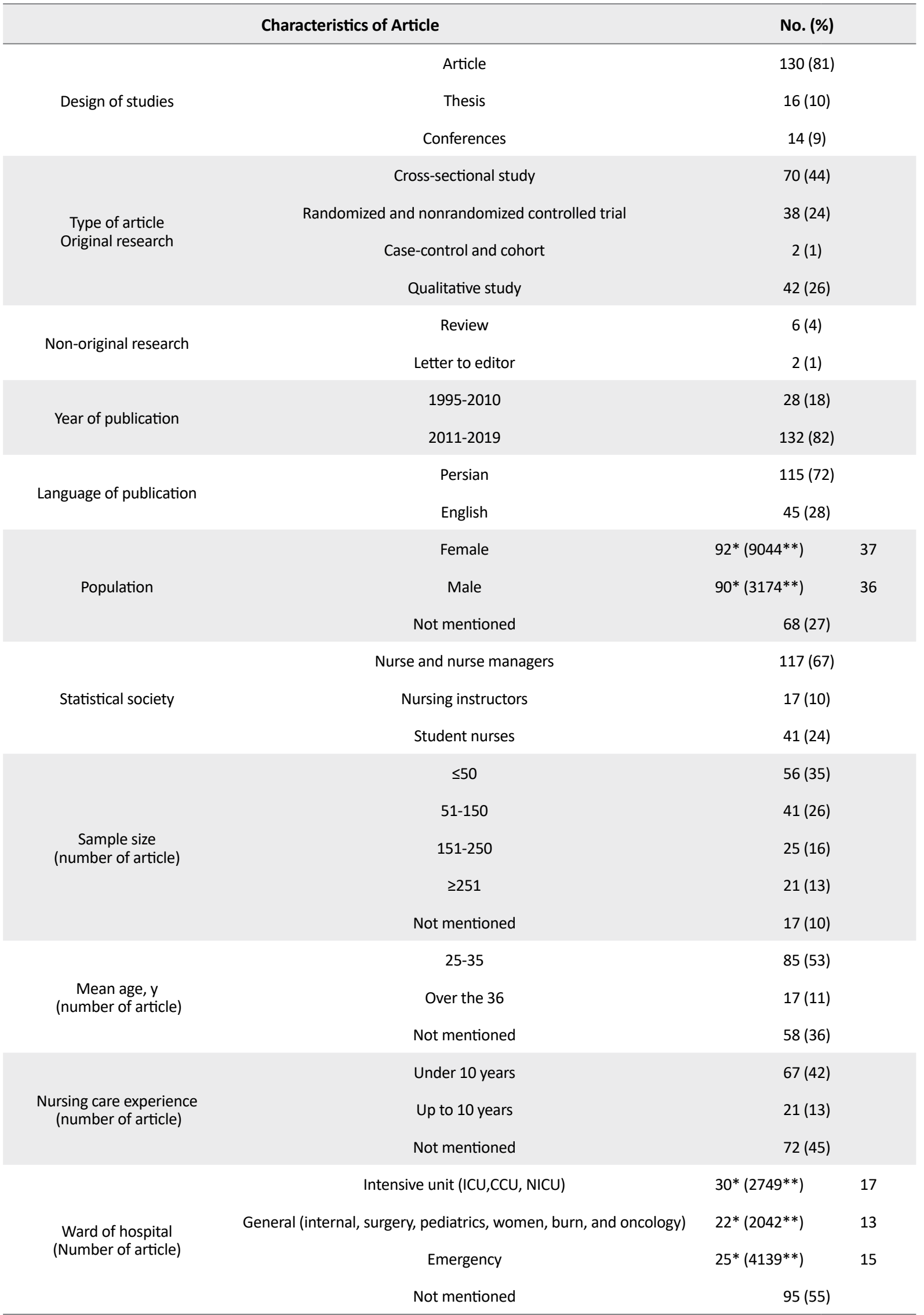




\begin{tabular}{|c|c|c|c|}
\hline \multicolumn{2}{|r|}{ Characteristics of Article } & \multicolumn{2}{|c|}{ No. (\%) } \\
\hline \multirow{3}{*}{$\begin{array}{l}\text { Level of education (number of } \\
\text { article) }\end{array}$} & BSc in nursing & $84^{*}\left(10548^{* *}\right)$ & 39 \\
\hline & MSc and higher & $53 *(1004 * *)$ & 25 \\
\hline & Not mentioned & 77 & 36 \\
\hline \multirow{4}{*}{$\begin{array}{l}\text { Level of competency (number } \\
\text { of article) }\end{array}$} & Low level & 10 & 6 \\
\hline & Moderate level & 22 & 14 \\
\hline & High level & 42 & 26 \\
\hline & Not mentioned & 86 & 54 \\
\hline \multirow{3}{*}{ Type of sampling } & Random sampling (probability sampling) & 43 & 27 \\
\hline & Nonrandom and census sampling (non-probability sampling) & 90 & 56 \\
\hline & Not mentioned & 27 & 17 \\
\hline \multirow{5}{*}{$\begin{array}{l}\text { Data collection tools except } \\
\text { reviews and letter to editors }\end{array}$} & Questionnaire & 75 & 40 \\
\hline & In-depth and semi-structured interviews and focus group & 35 & 18 \\
\hline & Skills checklist and performance observation & 22 & 12 \\
\hline & Self-structured questionnaire, psychometric, and tool design & 19 & 10 \\
\hline & Quasi-experimental interventions & 38 & 20 \\
\hline
\end{tabular}

evaluation of clinical competency, the researchers could not reach a collective agreement regarding the areas in which the nurses obtained the highest scores. Nonetheless, the nurses obtained the lowest scores on quality guarantee, in the majority of studies.

\section{Theme 2: Nursing competency dimensions}

Based on the findings, a nurse must have moral, clinical and special (perceptual), cultural, emotional, and motivational competency. The moral dimension includes moral personality (altruism, searching for meaning, being a pioneer, perfectionism, self-control, honesty, forgiveness, building appropriate human relations, social principles, religious commitment, professional commitment, attention to the totality of human existence, and humanistic view towards patients), moral care (dignified care, safe care, fair care, and comprehensive care), and moral decision-making (moral sensitivity, moral thinking, moral reasoning, and moral courage).

The clinical and special (perceptual) dimension includes scientific knowledge, special skills, routine and emergency cares, the provision of scientific care based on patient's needs and conditions, maintaining patient safety, the acceptance of and coordination with nursing practices, self-orientation in clinical learning, patient care skills, the development of professional behaviors, personal development, the effectiveness of nursing education, perceptual ability, critical thinking, and decision-making. The cultural dimension consists of three subthemes of cultural attitude, cultural knowledge, and cultural skills.

The emotional and motivational dimension that is called emotional competency includes personal emotional competency (positive attitude, spiritual maturity, emotional self-control, adherence to professional ethics, creativity, and innovation) and social-emotional competency (communication management and compassionate care) (Gholampour et al., 2018; Nehrir et al., 2016; Bahrami et al., 2018; Zafarnia et al., 2017; Jouzi, Vanaki \& Mohammadi 2015; Haghigh et al., 2017).

Hajbagheri et al. compared the universities of Iran with those of other countries, regarding the expected competencies from nursing $\mathrm{PhD}$ candidates. The results indicated that the nursing $\mathrm{PhD}$ curriculum was quite rich since it involved all features for students' competency. These features included science production and transfer, performance in nursing research, nursing teaching and learning, management and leadership, theorization, sta- 
Table 3. Psychometric characteristics of nurses' competency instruments used in Iran

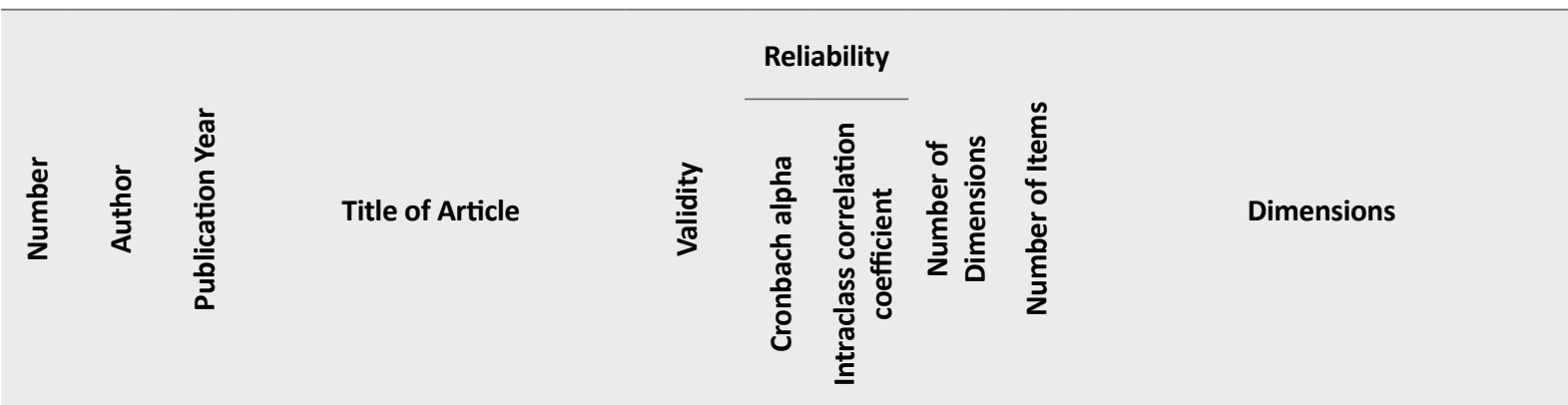

4 factors for teacher: commitment and follow-up on effectiveness of theoretical and clinical education, student development, ethics and teacher character, com-

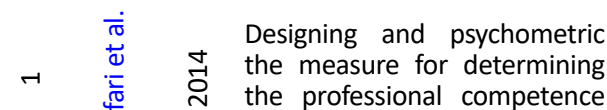
of nursing faculty members mitment and seriousness to strengthen ने $\vec{\sigma}$ o $\quad \infty \quad \infty \quad$ o research capacity, and 4 factors for students: commitment and follow-up on effectiveness of theoretical and clinical education, student development, ethics and teacher character, educational/ research management ability for student questionnaire

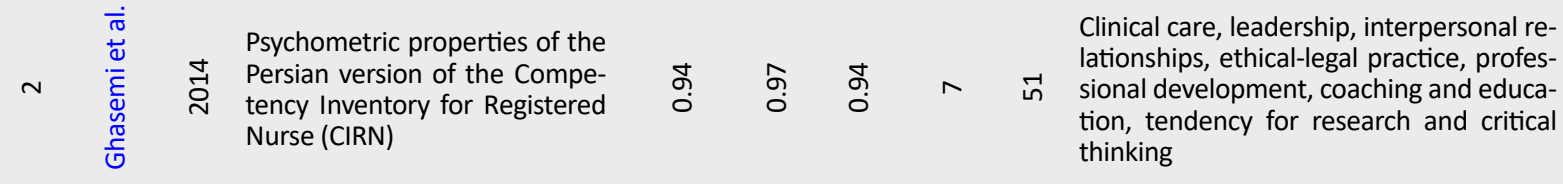

\begin{tabular}{|c|c|c|c|c|c|c|c|c|c|}
\hline$m$ & $\begin{array}{l}\frac{\dot{\pi}}{\pi} \\
\frac{\pi}{0} \\
\frac{\pi}{\pi} \\
\frac{\pi}{\frac{\pi}{2}}\end{array}$ & $\stackrel{m}{\stackrel{n}{\nu}}$ & $\begin{array}{l}\text { Validity and reliability of a } \\
\text { Persian version of nursing stu- } \\
\text { dents' competence scale in } \\
\text { spiritual care }\end{array}$ & 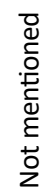 & $\underset{\hat{0}}{\hat{N}}$ & 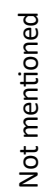 & 6 & $\grave{N}$ & $\begin{array}{l}\text { assessment and implementation of spiri- } \\
\text { tual care, professionalization and improv- } \\
\text { ing the quality of spiritual care, personal } \\
\text { support and patient counseling, referral } \\
\text { to professionals, attitude towards the pa- } \\
\text { tient's spirituality, communication }\end{array}$ \\
\hline
\end{tabular}

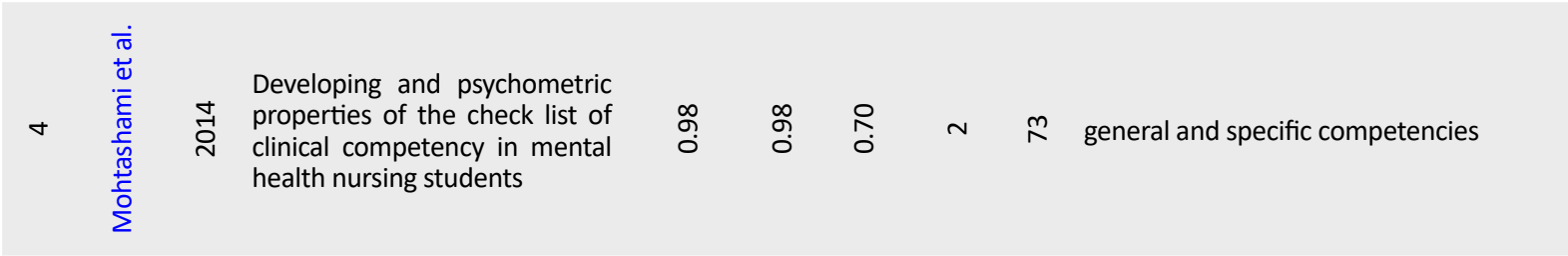

Development and psychomet$\checkmark$ ric testing for nursing students clinical competence instrument in internship practicum

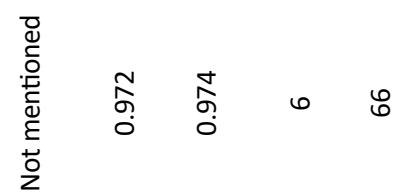

Patient-centered care, acceptance and professional role play, reasoning for care delivery, ability to adhere to ethics (working conscience), ability to manage care and accountability, and accountability

Development and psychomet-

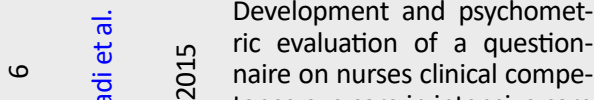

tence eye care in intensive care unit patients

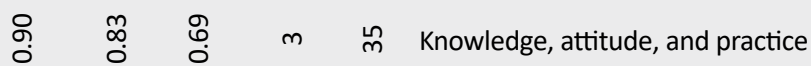



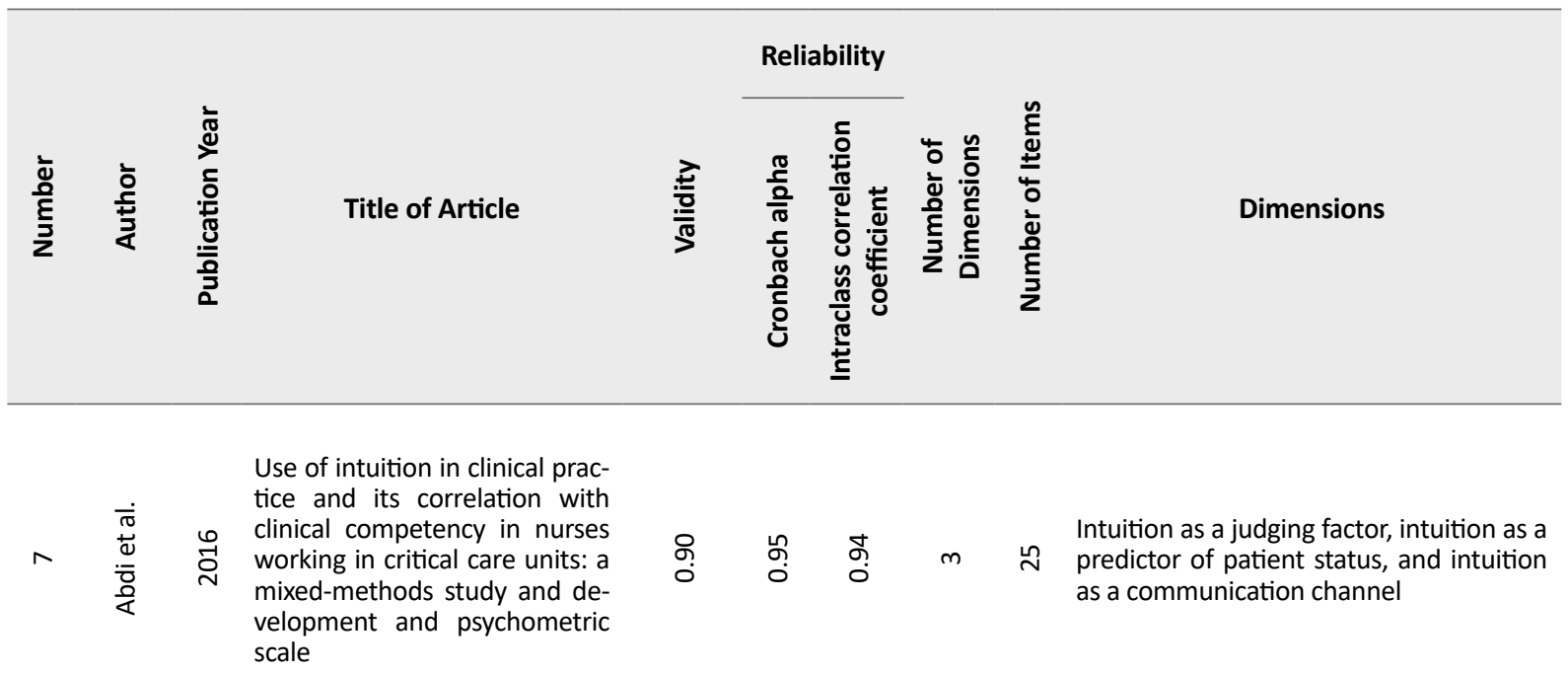
○ $\leftarrow$ Intuition as a judging factor, intuition as a ᄋำ

\begin{tabular}{|c|c|c|c|c|c|c|c|c|c|}
\hline$\infty$ & 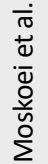 & 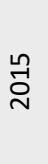 & $\begin{array}{l}\text { Development and psychomet- } \\
\text { ric properties rating scale of } \\
\text { "clinical competency evalua- } \\
\text { tion in mental health nurses": } \\
\text { exploratory factor analysis }\end{array}$ & م̆ & $\begin{array}{l}\infty \\
\text { ọ } \\
\text {. }\end{array}$ & @̊ & $\sim$ & 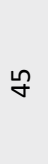 & $\begin{array}{l}\text { Emotional/moral and specific care com- } \\
\text { petencies }\end{array}$ \\
\hline
\end{tabular}

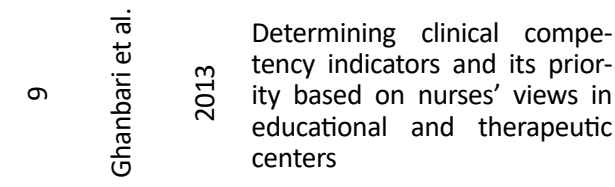

\begin{tabular}{|c|c|c|c|c|c|}
\hline 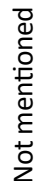 & 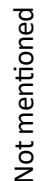 & 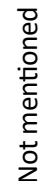 & $m$ & ஓి & $\begin{array}{l}\text { Three domains in general competencies: } \\
\text { communication, professional maturity, } \\
\text { and personality characteristics; two do- } \\
\text { mains in specific competencies: technical } \\
\text { capabilities and basic clinical skills }\end{array}$ \\
\hline
\end{tabular}

Client- Centered Nursing Care

tistical analysis, ethics orientation, article writing, using educational and research technologies, and interdisciplinary cooperation (Adib-Hajbaghery \& Hosieni 2018).

\section{Theme 3: Factors involved in clinical competency}

The included studies divided the effective factors in clinical competency into two categories: internal and external factors. The internal factors consisted of work experience (effective communication skills; the presentation of productive work practices, such as interest in the profession, responsibility, and accountability; clinical experience; decision-making; and critical thinking) and personal factors (professional skills, theoretical knowledge, adherence to ethical standards and professional commitment, respecting oneself and others, sufficient self-confidence, strong conscience, students' sociocultural status, and cultural differences between students and nurses).

Moreover, the external factors included the environmental factors associated with the educational system (organizational support, organizational learning, efficient educational system, the provision of sufficient information technologies, unclarified objectives, instructors' insufficient skills in teaching this novel major, tyranny of physicians in their behaviors towards clinical nurses, patients and nursing instructors, and not accepting care in the clinical environment), professional and motivational factors (the empowerment of students in education and research, proper professional position after graduation, not paying attention to the students' interests at the beginning of the course, change in viewpoints and insights after graduation, and the lack of organizational position for students), and managerial factors (meritocracy among nurses in different majors, nursing managers' leadership styles, effective management in the educational system, the quality of working life, performance management, control mechanisms, supervision, work permit, and appropriate facilities) (Memarian et al., 2007; Vanaki \& Memarian 2009; Purfarzad et al., 2019; Jouzi, Vanak \& Mohammadi, 2014; Barkhordari-Sharifabad et al., 2018). 
Theme 4: The relationship between nursing competency and other variables

several studies have explored the relationships between clinical competency and other variables. Based on the results, nursing competency was significantly and directly associated with emotional intelligence, the quality of working life, job satisfaction, intuitive and rational decision-making styles, spiritual intelligence, organizational commitment, student work, motivation, self-efficacy, patient satisfaction, sympathy, spiritual health, productivity, knowledge management, marital status, employment status, and interest in the profession. An increase in the abovementioned factors led to an increase in the nurses' competency, particularly clinical competency (Manouchehri et al., 2018; Mirlashari et al., 2016; Zarei et al., 2019; Hasimi et al., 2014). However, some studies revealed no significant relationships between the nurses' competency, job satisfaction, and organizational commitment (Karami \& Foroughameri 2017). Among the other variables unrelated to clinical competency were the concept of intuition, professional ethics, and using intuition in clinical practice (Hassani et al., 2017). Moreover, competency was negatively related to occupational stress, occupational burnout, and the increased years of education (Soroush et al., 2016). Accordingly, an increase in the occupational stress of the bachelor and master students, occupational burnout, and the years of education led to a decline in competency levels (Komeili-Sani et al., 2015; Soroush et al., 2016; Badrani 2018; Khorashadizadeh et al., 2019).

Theme 5: Effective strategies in the promotion of clinical competency

One of the most important challenges in nursing management is the maintenance and promotion of competency among nurses, particularly novice ones. These nurses deviate from professional criteria and standards very frequently; these deviations eventually result in mal-performance in care provision. Therefore, this has been considered to be an actual need and an important mission on the part of nursing managers (Oermann \& Garvin 2002). This phenomenon has received much attention in the nursing education of Iran. Studies have also proposed, executed, and evaluated some strategies, including competency-based participatory continuing education (Memarian et al., 2015; Kavosi 2015), care-oriented professional cooperation in training apprenticeship courses (Nobakht, Abedi \& Elahi 2016), the transfer of knowledge and experience through storytelling (Ghasemi et al., 2012), the optimization of managerial skills (Rahimaghaee et al., 2015), multi-monitoring training
(Hosseinabadi et al., 2015), reflective educational strategies (Mousavi, Yousefi \& Sadat 2018), educational portfolio (Sedaghat et al., 2014), achievement-based training (Valizadeh et al., 2009), competency-based mastery pattern (Soheili et al., 2015), nursing mentors committee or the positioning of experienced nurses as nursing mentors (Jaafari Golestan \& Memarian, 2009), situational leadership model (Purfarzad et al., 2019), the effectiveness of online simulator (Moghbal, Sajjadi \& Soltani 2018), risk management in hospitals (Rajabi \& Arsalani, 2017), supportive clinical environment during apprenticeship (Mashmool Aman Mohammad et al., 2018), disaster management training (Latif, Abasi \& Momenian 2019), stress inoculation training (Sargazi et al., 2018), multimedia training (Ebadi et al., 2015), and tailored graduate program based on needs, compatibility, and performance (Shahsavari et al., 2017). Hassandoust et al. introduced the prioritization of clinical competency indices as a strategy for reducing the gap between theory and practice, which could enhance clinical competency. They also proposed a structured model with three domains of building relationships (10 items), disaster management ( 8 items), and personal features (12 items), using the Delphi technique (Hasandoost et al., 2015). Table 2 presents the information related to the executive processes as well as the results of the intervention.

As a study limitation, the comparison of the results was highly difficult, because all types of investigations with various sample sizes and research populations were entered into the study. Some studies revealed the positive impact of a variable on clinical competency, while some others showed a negative and reverse relationship and some reported no results. Therefore, the researchers could not reach a collective agreement in this regard. Furthermore, to assess the nurses' competency, studies have used various questionnaires, which hindered the comparison of the findings and reaching an agreement. Another major limitation of the study was that the nurses' competency was mostly evaluated via self-assessment. Finally, the researchers made attempts to discuss the most important findings of the included studies, but all the details related to the dimensions could not be presented.

Considering the great heterogeneity among the findings of the included studies, future systematic reviews are recommended to determine the levels of the different types of clinical competency among nurses, based on clinical wards and work experience. Moreover, considering the numerous strategies for the improvement of clinical competency, further studies, particularly experimental ones with larger sample sizes are recommended to achieve stronger results. Besides, qualitative studies 
are necessary to explore the executive barriers against the effective strategies in the different types of competency among nurses.

\section{Conclusion}

In order to promote the quality of healthcare in the national health system, emphasis should be put on the employment of competent forces. The present scoping review provided a comprehensive view of nursing competency. In this study, most evidences were obtained from primary quantitative investigations. Yet, further comprehensive studies in countries with wide-ranging databanks are required to achieve more reliable results.

The studies that were entered into the study did not reach a collective consensus on the relationship between some variables and nursing competency. Besides, the use of different questionnaires made the comparison difficult. Therefore, further research is recommended in this area. Overall, the study results could be beneficial for nursing managers in clinical settings, policymakers, and nursing instructors to plan for the promotion of nursing competency.

\section{Ethical Considerations}

\section{Compliance with ethical guidelines}

This project has been registered in the research committee of Ahvaz Jundishapur University of Medical Sciences (Code: IR.AJUMS.REC.1399.121).

\section{Funding}

This study was supported by the Research Affairs of Ahvaz Jundishapur University of Medical Sciences (JUMS).

\section{Authors' contributions}

Both authors contributed to study conception and design, data collection, data analysis and interpretation, drafting the manuscript or revising it critically for important intellectual content.

\section{Conflict of interest}

The authors declared no conflict of interests.

\section{Acknowledgments}

The authors would like to thank the Vice-Chancellor for the Research Affairs of Ahvaz Jundishapur Univer- sity of Medical Sciences (JUMS) for the financial supporting of this project. The student research committee of JUMS and all individuals who cooperated in the research are also appreciated.

\section{References}

Adib-Hajbaghery, M., \& Hosieni, F., 2018. Comparison of expected potentials of $\mathrm{PhD}$ nursing students in Iran and top universities of the world. Iran Journal of Nursing (IJN), 31(113), pp. 30-41. [DOI:10.29252/ijn.31.113.30]

Adib-Hajbaghery, M., Zehtabchi, S., \& Fini, I., 2017. Iranian nurses' professional competence in spiritual care in 2014. Nursing Ethics, 24(4), pp. 462-73. [DOI:10.1177/0969733015600910] [PMID]

Aghamolayee, T., et al., 2008. [Quality of primary health services from the viewpoints of the women referring to Bandar Abbas Health Centers (Persian)]. Payesh Health Monit, 7(2), pp. 121-7. http://payeshjournal.ir/article-1-664-en.html

Alavi, M., \& Irajpour, A., 2014. [Optimum characteristics of nursing students' clinical evaluation: Clinical nursing teachers' viewpoints in Isfahan University of Medical Sciences (Persian)]. Iranian Journal of Medical Education, 13(10), pp. 796-808. http:// ijme.mui.ac.ir/article-1-2876-en.html

Aliakbari, F., \& Aein, F., 2017. [Assessing Isfahan emergency nurse competence in disaster response by using national questionnaire (Persian)]. Journal of Clinical Nursing and Midwifery, 6(3), pp. 1-10. http://eprints.skums.ac.ir/6158/1/8015.pdf

Arksey, H., \& O'malley, L., 2005. Scoping studies: Towards a methodological framework. International Journal of Social Research Methodology, 8(1), pp. 19-32. [DOI:10.1080/1364557032000119616]

Atashzadeh-Shoorideh, F., et al., 2018. Effectiveness of implementation of "mental health nursing students' clinical competency model" on academic performance of nursing students. F1000Research, 7, p. 1212. [DOI:10.12688/f1000research.14284.1] [PMID] [PMCID]

Azemian, A., 2014. The standards of professionalism in nursing The nursing instructors' experiences. Evidence Based Care, 4, pp. 27-40. [DOI:10.7748/ns2013.06.27.40.26.s35]

Badrani, M. R., 2018. [The relationship between job stress and teamwork and clinical competence in nurses working in Khatam Alanbia Hospital in Shooshtar (Persian)]. 20 $0^{\text {th }}$ Annual Research Congress of Medical Students of Iran, Kermanshah - Student Research Committee of Kermanshah University of Medical Sciences. https://civilica.com/doc/944501/

Bahrami, M., Aliakbari, F., \& Aein, F., 2014. Investigation of competencies of nurses in disaster response by utilizing objective structured clinical examination. Iranian Journal of Nursing and Midwifery Research, 19 (7 Supp11), pp. S1-S6. [PMCID] [PMID]

Bahrami, M., et al., 2018. Emotional competence: A core competence in gerontological nursing in Iran. International Journal of Older People Nursing, 13(4), p. e12210. [DOI:10.1111/opn.12210] [PMID]

Bahreini, M., et al., 2011. Comparison of head nurses and practicing nurses in nurse competence assessment. Iranian Journal 
of Nursing And Midwifery Research, 16(3), pp. 227-34. https:// www.ncbi.nlm.nih.gov/pmc/articles/PMC3249804/

Barkhordari-Sharifabad, M., et al., 2018. Ethical competency of nurse leaders: A qualitative study. Ursing Ethics, 25(1), pp. 2036. [DOI:10.1177/0969733016652125] [PMID]

Bastami, M. R., et al., 2016. Assessment of cultural competence among nurses. Medical Ethics Journal, 10(36), pp. 65-72. [DOI:10.21859/mej-103665]

Cowin, L. S., et al., 2008. Competency measurements: Testing convergent validity for two measures. Journal of Advanced Nursing, 64(3), pp. 272-77. [DOI:10.1111/j.1365-2648.2008.04774.x] [PMID]

Daudt, H. M., Van Mossel, C., \& Scott, S. J., 2013. Enhancing the scoping study methodology: A large, inter-professional team's experience with Arksey and O'Malley's framework. BMC Medical Research Methodology, 13, p. 48. [DOI:10.1186/14712288-13-48] [PMID] [PMCID]

Denisco, S. M., 2019. Advanced practice nursing: Essential knowledge for the profession, Burlington, Jones \& Bartlett Publishers. https:// books.google.com/books?id=XYiHCgA AQBAJ\&printsec $=$ frontcover\&dq $=$

Ebadi, A., et al., 2015. Assessment competency of nurses in biological incidents. Trauma Monthly, 20(4), p. e25607. [DOI:10.5812/traumamon.25607]

Ebrahimian, T., et al., 2017. Evaluation of the nursing services quality from the patient perspective by using the Kano and SERVQUAL combines model. Health Research Journal, 2(2), pp. 117-23. [DOI:10.18869/acadpub.hrjbaq.2.2.117]

Elhami, S., et al., 2018. Self-evaluation of nurses clinical competency based on benner theory. World Family Medicine Journal: Incorporating the Middle East Journal of Family Medicine, 16(3), pp. 191-7. https:// platform.almanhal.com/Files/Articles/117615

Epstein, R. M., \& Hundert, E. M., 2002. Defining and assessing professional competence. Journal of the American Medical Association, 287(2), pp. 226-35. [DOI:10.1001/jama.287.2.226] [PMID]

Ghanbari, A., et al., 2017. Assessing emergency nurses' clinical competency: An exploratory factor analysis study. Iranian Journal of Nursing and Midwifery Research, 22(4), pp. 280-6. [DOI:10.4103/1735-9066.212990] [PMID] [PMCID]

Ghasemi, K., et al., 2012. The effect of tacit knowledge transfer on nursing clinical competency. Archives of Rehabilitation, 12(49), pp. 8-13. https://rehabilitationj.uswr.ac.ir/browse. php?a_code $=\mathrm{A}-10-876-4 \& \mathrm{ftxt}=1$

Ghasemi, E., et al., 2014. [Psychometric properties of Persian version of the Competency Inventory for Registered Nurse (CIRN) (Persian)]. Iran Journal of Nursing, 27(87), pp. 1-13. http://ijn. iums.ac.ir/article-1-1743-en.html

Ghanbari, A., et al., 2017. Assessing emergency nurses' clinical competency: An exploratory factor analysis study. Iranian Journal of Nursing and Midwifery Research, 22(4), pp. 280-6.

Ghodsbin, F., \& Shafakhah, M., 2008. [Facilitating and preventing factors in learning clinical skills from the viewpoints of the third year students of fatemeh school of nursing and midwifery (Persian)]. Iranian Journal of Medical Education, 7(2), pp. 343-52. http:/ /ijme.mui.ac.ir/browse.php?a_id=720\&sid=1\&slc lang=en\&ppup $=$

Gholampour, M., et al., 2018. [Nurses' experiences about ethical and clinical competencies: A phenomenological approach (Persian)]. Bioethics Journal, 8(29), pp. 13-41. https://www.semanticscholar.org/paper/

Vafaee Najar, A., et al., 2011. [The effect of improvement of nursing managers' professional competencies based on performance on their productivity: An interventional study (Persian)]. Daneshva Medicine, 18(94), pp. 73-80. https://www.sid.ir/fa/journal/ ViewPaper.aspx?id=148475

Haghigh, S., et al., 2017. A survey on knowledge level of the nurses about hospital Triage. Journal of Nursing Education (JNE), 5(6), pp. 46-52. [DOI:10.21859/jne-05067]

Hasandoost, F., et al., 2015. [Prioritization of general clinical competence indicators from nurses' view employed in emergency wards (Persian)]. Journal of Holistic Nursing And Midwifery, 25(4), pp. 53-63. http://hnmj.gums.ac.ir/article-1-579-en.html

Hasimi, L., et al., 2014. [The effect of applying organizational culture improvement model of patient education on anxiety and satisfaction of burned hospitalized patients: A clinical trial (Persian)]. Journal of Clinical Nursing and Midwifery, 3(3), pp. 16-28. http://eprints.skums.ac.ir/3537/1/48.pdf

Hassani, P., et al., 2017. Relationship between the use of intuition in clinical practice and the clinical competence of critical care nurses. International Journal of Evidence-Based Healthcare, 15(4), pp. 171-7. [DOI:10.1097/XEB.0000000000000113] [PMID]

Heydari, A., Kareshki, H., \& Armat, M. R., 2016. Is nurses' professional competence related to their personality and emotional intelligence? a cross-sectional study. Journal of Caring Sciences, 5(2), pp. 121-32. [DOI:10.15171/jcs.2016.013] [PMID] [PMCID]

Hosseinabadi, R., et al., 2015. [Effect of multi mentoring educational method on clinical competence of nursing students (Persian)] Journal of Medical Education, 10(2), pp. 119-28. http:/ /jmed.ssu. ac.ir/article-1-490-en.pdf

Jaafari Golestan, N., Vanki, Z., Memarian, R., 2009. [The impact of replacing experienced nurses on the role of nursing advisors on promoting the clinical competency of rookie nurses (Persian)] Iranian Journal of Medical Education, 7(2), pp. 237-47. https:// www.sid.ir/fa/journal/ViewPaper.aspx?id=71500

Jafari, H., et al., 2014. [Designing and psychometric the measure for determining the professional competence of nursing faculty members (Perasian)]. Journal of Nursing and Midwifery Sciences, 1(2), pp. 8-13. http://jnms.mazums.ac.ir/article-1-36-fa.html

Golestan, N. J., Vanaki, Z., \& Memarian, R., 2008. Organizing "Nursing Mentors Committee": An effective strategy for improving novice nurses' clinical competency. Iranian Journal of Medical Education, 7(2), pp. 237-47. https:/ / vlibrary.emro.who. int/imemr/

Jahanshahi, Z., et al., 2017. The correlation between the clinical competency and empathy of nurses: Case study, intensive care units of the educational hospitals of Kerman Medical Sciences University, Iran. Annals of Tropical Medicine and Public Health, 10(3), pp. 694-701. https://www.atmph.org/article.asp?issn=1755 6783 ; year $=2017$; volume $=10 ;$ issue $=3 ;$ spage $=694 ;$ epage $=701$; aul ast=Jahanshahi;type $=3$

Jouzi, M., Vanaki, Z., \& Mohammadi, E., 2015. Factors affecting the communication competence in Iranian nursing students: A 
qualitative study. Iranian Red Crescent Medical Journal, 17(3), p. e19660. [DOI:10.5812/ircmj.19660] [PMID] [PMCID]

Jouzi, M., Vanak, Z., \& Mohammadi, E., 2014. The essence of nursing student's clinical competency in internship period: Humanistic patient-centered care. Journal of Education and Ethics in Nursing 2(4), pp. 51-9. http:// ethic.jums.ac.ir/article-1-115-en.html

Karami, A., Farokhzadian, J., \& Foroughameri, G., 2017. Nurses' professional competency and organizational commitment: Is it important for human resource management? PloS One, 12(11), p e0187863. [DOI:10.1371/journal.pone.0187863] [PMID] [PMCID]

Karimi-Moonaghi, H., et al., 2015. Relation between spiritual intelligence and clinical competency of nurses in Iran. Iranian Journal of Nursing and Midwifery Research, 20(6), pp. 665-9. [DOI:10.4103/1735-9066.170002] [PMID] [PMCID]

Kashf, S. M., Rakhshani, T., \& Hashemi, H., 2019. Evaluation the quality of health services based on SERVQUAL Model in Ahwaz Health Care Centers, Iran. Caspian Journal of Health Research, 4(1), pp. 1-5. [DOI:10.29252/cjhr.4.1.1]

Kavosi, A., 2015. [Effect of continuing education competencybased program for emergency nurses on rate CPR successful (Persain)]. Quarterly Journal of Nersing Management, 4(2), pp. 19-28. http://ijnv.ir/article-1-200-en.html

Khorashadizade, F., et al., 2019. [Assessment of nurses' clinical competency in Imam Hasan Hospital, Bojnurd, Iran (Persian)]. Journal of North Khorasan University of Medical Sciences, 11(2), pp. 66-72. http://journal.nkums.ac.ir/article-1-1825-en. html

Komeili-Sani, M., et al., 2015. [The relationship between nurses clinical competency and job stress in Ahvaz university hospital, 2013 (Persain)]. Journal of Clinical Nursing and Midwifery, 4(1), pp. 39-49. http://eprints.skums.ac.ir/3513/1/24.pdf

Khalaj M., Pakpurhaji Haji Agha., A., \& Mohammadi Zaidi, E. 2013. [The validity and reliability of an instrument to assess nursing competencies in spiritual care (Persian)]. Qazvin University of Medical Sciences, 17(2 \& 67), pp. 64-77. https:/ / www sid.ir/fa/journal/ViewPaper.aspx?ID=202099

Landa, J. M. A., \& López-Zafra, E., 2010. The impact of emotional intelligence on nursing: An overview. Psychology, 1(1), p. 50 [DOI:10.4236/psych.2010.11008]

Latif, M., Abasi, M., \& Momenian, S., 2019. [The impact of disaster and disaster education on promotion of nurses' professional competence in response to crisis in Chamran Saveh Hospital, 1977 (Persian)]. $9^{\text {th }}$ International Congress on Disasters and Disasters, Tehran, Iran, Viewed 18 April 2021, https:/ / civilica.com/doc/929542/

Liu, M., et al., 2009. Competency inventory for registered nurses in Macao: Instrument validation. Journal of Advanced Nursing, 65(4), pp. 893-900. [DOI:10.1111/j.1365-2648.2008.04936.x] [PMID]

Mahmoodi, A., Khani, L., \& Ghaffari, M., 2017. [The relationship of cultural competence and responsibility with nurses attitude toward patient's right: The mediating role of ethical beliefs (Persian)]. Journal of Medical Ethics and History of Medicine, 9(5), pp. 39-51. http://ijme.tums.ac.ir/article-1-5823-en.html

Manouchehri, H., et al., 2018. [Lived experiences nursing managers about the role of students' work in attaining clinical competency newly nurses (Persian)]. Quarterly Journal of Nersing Management, 7(1), pp. 29-40. [DOI:10.29252/ijnv.7.1.29]
Mazlum, S., \& Nejad, M. R., 2016. Investigate the relationship between clinical competence and self-efficacy in Nursing University of Medical Sciences of Zahedan. Research Journal of Medical Sciences, 10(6), pp. 669-75. https://medwelljournals. com/abstract/?doi=rjmsci.2016.669.675

Memarian, R., et al., 2015. [Effect of competency-based-training program on resuscitation outcomes (Persian)]. Journal of Research Development in Nursing \& Midwifery, 11(2), pp. 22-30. http://nmj.goums.ac.ir/article-1-623-en.pdf

Memarian, R., et al., 2007. Professional ethics as an important factor in clinical competency in nursing. Nursing Ethics, 14(2), pp. 203-14. [DOI:10.1177/0969733007073715] [PMID]

Mirlashari, J., et al., 2016. Clinical competence and its related factors of nurses in neonatal intensive care units. Journal of Caring Sciences, 5(4), pp. 317-24. [DOI:10.15171/jcs.2016.033] [PMID] [PMCID]

Moghbal, M., Sajjadi, M., \& Soltani, M., 2018. The effectiveness of online predictor on the clinical competency of nursing students in mechanical ventilation. $13^{\text {th }}$ Annual Congress of Medical Students of Eastern Medical Sciences, Birjand University of Medical Sciences, Iran, Birjand. https://en.civilica. com/doc/899335/

Mousavi, S. S., Yousefi, S. M., \& Sadat, M., 2018. The effect of promoting clinical competency on the nurses occupational quality of life at the pediatric wards. Iranian Journal of Nursing Research,13(2), pp. 33-9. http://ijnr.ir/browse.php?a $\mathrm{id}=1868 \&$ sid $=1 \&$ slc_lang $=$ en\&ftxt $=1$

Mohtashami, J., et al., 2014. [Developing and psychometric properties check list of clinical competency in mental health nursing students (Persian)]. Iranian Journal of Psychiatric Nursing, 2(3), pp. 46-57. http://ijpn.ir/article-1-398-en.html

Nesami, M., et al., 2009. [Concept analysis of competency in nursing: Qualitative research (Persian)]. Journal of Mazandaran University of Medical Sciences, 18(67), pp. 35-42. http:/ /jmums. mazums.ac.ir/files/site1/user_files_0d0bf0/admin-A-10-1490-bcd3ac4.pdf

Nehrir, B., et al., 2016. Competency in nursing students: A systematic review. International Journal of Travel Medicine and Global Health, 4(1), pp. 3-11. [DOI:10.20286/ijtmgh-04013]

Nobakht, M., Abedi, H. A., \& Elahi, N., 2016. [Investigating the effect of professional partnership Care-oriented teaching model on nursing students' psychomotor clinical competencies (Persian)]. Research in Curriculum Planning, 13(49), pp. 61-9. http://jsr-e.khuisf.ac.ir/article_534433.html

Oermann, H., \& Garvin, F., 2002. Stresses and challenges for new graduates in hospitals. Nurse Education Today, 22(3), pp. 225-30. [DOI:10.1054/nedt.2001.0695] [PMID]

Purfarzad, Z., et al., 2019. Effective factors for development of gerontological nursing competence: A qualitative study. The Journal of Continuing Education in Nursing, 50(3), pp. 127-133. [DOI:10.3928/00220124-20190218-08] [PMID]

Rahimaghaee, F., et al., 2015. [Efficiency of staff development program and its relationship (Persian)]. Journal of Holistic Nursing and Midwifery, 25(4), pp. 73-80. http://hnmj.gums. ac.ir/article-1-581-en.html

Rajabi, S. K. H., 2017. The Impact of hospital risk management implementation on hospital readiness and nurses' professional competence in response to disasters and disasters in 
Rafideh Hospital (Master thesis), University of Rehabilitation Sciences and Social Welfare. https://dl.uswr.ac.ir/handle/ Hannan/137348

Ramezanzade Tabriz, E., Orooji, A., \& Bikverdi, M., 2017. Investigation clinical competence and its relationship with professional ethics and spiritual health in nurses. Health, Spirituality and Medical Ethics, 4(1), pp. 2-9. http://jhsme.muq.ac.ir/article1-123-en.html

Sargazi, O., et al., 2018. Improving the professional competency of psychiatric nurses: Results of a stress inoculation training program. Psychiatry Research, 270, pp. 682-687. [DOI:10.1016/j.psychres.2018.10.057] [PMID]

Sedaghat, S., et al., 2014. [The effect of portfolios training on nursing students' clinical competence (Persian)]. Educational Development of Judishapur, 5(3), pp. 191-8. http://journals.ajums.ac.ir/ article_79702.html?lang=en

Shahsavari, H., et al., 2017. Effect of a clinical skills refresher course on the clinical performance, anxiety and self-efficacy of the final year undergraduate nursing students. Nurse Education in Practice, 27, pp. 151-6. [DOI:10.1016/j.nepr.2017.08.006] [PMID]

Soheili, A., et al., 2015. The effect of implementing competencybased education model on nursing students' clinical performance in Coronary Care Unit (CCU). Nursing and Midwifery Journal, 13(4), pp. 728-38. https://web.a.ebscohost.com/abstract?

Soheilipour, K., \& Farajzadeh, Z., 2016. Evaluating the clinical competence of junior nursing staff based on self-assessmentin Valiasr Hospital of Birjand in 2015-16. Modern Care Journal, 13(4), p. e10089. [DOI:10.5812/modernc.10089]

Soroush, F., et al., 2016. The relationship between nurses' clinical competence and burnout in neonatal intensive care units. Iranian Journal of Nursing and Midwifery Research, 21(4), pp. 424-29. [DOI:10.4103/1735-9066.185596] [PMID] [PMCID]

Tarrahi, M., 2012. [The quality of health care services provided in health care centers of Khorramabad using SERVQUAL model in 2010 (Persian)]. Yafteh, 14(1), pp. 12-21. https:/ / www.sid.ir/en/ journal/ViewPaper.aspx?ID=556802

Tomar, R., 2016. A study of emotional intelligence among nurses. International Journal of Nursing Research (IJNR), 4, pp. 5204-11. [DOI:10.18535/ijsre/v4i04.16]

Tricco, A. C., et al., 2018. PRISMA extension for scoping reviews (PRISMA-ScR): Checklist and explanation. Annals of Internal Medicine, 169(7), pp. 467-73. [DOI:10.7326/M18-0850] [PMID]

Tzeng, H. M., 2004. Nurses' self-assessment of their nursing competencies, job demands and job performance in the Taiwan hospital system. International Journal of Nursing Studies, 41(5), pp. 487-96. [DOI:10.1016/j.ijnurstu.2003.12.002] [PMID]

Valizadeh, S., et al., 2009. [The effect of outcome-based education on nursing students' clinical competency (Persian)]. Iranian Journal of Medical Education, 9(2), pp. 157-65. http:/ / ijme.mui.ac.ir/article1-975-en.html

Vanaki, Z., \& Memarian, R., 2009. Professional ethics: Beyond the clinical competency. Journal of Professional Nursing, 25(5), pp. 28591. [DOI:10.1016/j.profnurs.2009.01.009] [PMID]

Zafarnia, N., et al. 2017. Moral competency: Meta-competence of nursing care. Electronic Physician, 9(6), pp. 4553-62. [DOI:10.19082/4553] [PMID] [PMCID]
Zarei, B., et al., 2019. Empathy and cultural competence in clinical nurses: A structural equation modelling approach. Nursing Ethics, $26(7$ \& 8), pp. 2113-23. [DOI:10.1177/0969733018824794] [PMID] 
This Page Intentionally Left Blank 